\title{
THE DEVELOPMENT OF LOCAL ECOLOGICAL NETWORKS IN UKRAINE: THE EXAMPLE OF LVIV REGION
}

\author{
Nataliia Stoiko, Oksana Cherechon \\ Lviv National Agrarian University
}

\begin{abstract}
The conservation and renovation of biological diversity of territories are of vital importance in Ukraine. The concept of ecological networks has laid the foundation of these issues. In Ukraine, the law "On the ecological network" was adopted, and ecological networks were developed at the regional level. However, most developments do not fully take into account the location of reserved territories and places of concentration of valuable flora and fauna, and also often do not correspond to the principle of formation of a holistic system, which significantly reduces their environmental significance and the expediency of practical implementation. The authors of the article consider that one should estimate the natural potential of the territories in detail and objectively, as well as provide recommendations for practical actions for the renovation of biological and landscape diversity. One can do it in the process of the development of local ecological networks (at the level of separate administrative regions and territorial communities). One has developed the structure of the ecological network on the example of Stryi district of Lviv region and determined the estimation of the spatial connectivity of its crucial elements. The problem is that most of the connecting territories are formed from semi-natural and unnatural lands (hayfields, pastures, arable lands), which complicates the practical side of the project implementation. One needs to develop an effective mechanism to encourage landowners and land users to carry out environmental activities; to increase investments in re-naturalization of lands; to conduct environmental education and environmental public awareness campaign; to provide local government and other stakeholders with consulting services for the development of ecological network development programs at the local level in Ukraine.
\end{abstract}

Key words: ecological network, local level, biological and landscape diversity, re-naturalization of lands.

\section{Introduction}

To begin with, the concept of ecological networks includes the creation of the model for conservation of biological diversity of territories, and at the same time it maintains the sustainable use of natural resources (Bennett G., Wit P., 2001). First of all, ecological networks combine natural ecosystems in order to preserve habitats and the growth of valuable flora and fauna species, the development of ways of animals' migration due to a combination of territories that are of vital importance for the environment protection. Thus it facilitates the genetic exchange between diverse populations. In addition, this concept is an instrument for implementing environmental policies, environmental design and physical planning for degraded ecosystems restoration and enhancement of the biodiversity value of anthropogenic landscapes (Bennett G., Mulongoy K. J., 2006; Jongman R.H.G, Külvik M., Kristiansen I., 2004).

Nevertheless the concept of ecological networks contributes to multifunctional landscapes planning (Opdam P., Steingröver E., Van Rooij S., 2006) in spite of the fact that in European countries one still hashes out institutional and financial problems of nature protection and land policies while implementing this concept, and it is criticized (Boitani L., Falcucci A. Maiorano L, Rondinini C., 2007).

Ukraine supports the idea of creating European Ecological network as the single spatial system of territories of European countries with a natural or partially altered landscape state. In Ukraine an appropriate legislation has been developed regarding the formation of the National Ecological network and ecological networks at the regional and local levels. The environmental policy of Ukraine implies an increase in the areas of protected territories, which are the foundation for ecological networks formation. The indicator of the reservation of the territory of the country (the ratio of the actual area of the Nature Reserve Fund to the area of the state) as at the $1^{\text {st }}$ of January 2018 was $6.6 \%$. Although this indicator is significantly lower than the one of European countries, there is still a positive tendency to increase the reserved areas in Ukraine. So, the quantity of nature reserves and national natural parks 
increased by 42 objects, and their area increased by 1109.9 thousand hectares during the years of 2000-2017 (Statistical Yearbook ..., 2017).

However, Ukrainian territories with natural flora and fauna are located mostly fragmentarily, this fact reduces their resistance to negative natural phenomena and anthropogenic processes as well as it also weakens the reproduction possibilities of living organisms. This situation presents the momentousness of the formation of ecological network, mainly green corridors, in order to connect the centers of the existence of natural flora and fauna and its migration.

In the Ukrainian legislation, the structural elements of the ecological network include: key territories which are intended to preserve the most valuable and typical landscape and biodiversity components for a certain region; connecting territories which are intended to combine key areas among themselves in order to ensure the migration of animals and the exchange of genetic heritage; buffer territories which are intended to protect key and connecting territories from external negative impacts; renewable territories which are intended to form the spatial integrity of the ecological network, within which measures of high priority for the reproduction of the primary natural state should be implemented (On Ecological network ..., 2004).

The planning of the national ecological network and ecological networks of the regional level was carried out due to the National Program for Creating the National Ecological network of Ukraine for the years of 2000-2015. It is certainly an essential stage in the implementation of the goal of national environmental policy, which envisages the stabilization and improvement of the natural environment of Ukraine. However, experts suggest that these developments are characterized by certain disadvantages, namely: most of ecological networks have a generalized structure, and the places of concentration of priceless flora and fauna are not fully taken into consideration, which significantly reduces their environmental significance and the feasibility of practical implementation; these networks do not fully correspond to the principle of forming an integral system that maximizes the continuity and interconnectedness of the structural elements of ecological networks; buffer territories, which promote the strengthening of the network and its protection from the influence of negative external factors, are not always designed around the key territories (ecological cores and green corridors) (Kahalo O., 2009; Kostiushyn V., Vasyliuk O., Kolomytsev H., 2011). There is virtually no research on renewable territories, which are means of landscapes re-naturalization in the available materials on the implementation of the concept of ecological networks.

The above-mentioned arguments show that the issue of developing ecological networks at the local level (at the level of certain administrative districts and territorial communities) is relevant for Ukraine. It will allow assessing the natural potential of the territories in detail and objectively, as well as providing recommendations for practical actions to restore biological and landscape diversity.

The aim of the work is to study the possibility of developing an ecological network of the local level as an important prerequisite for the conservation and restoration of biological diversity of territories in Ukraine due to the increase of the area of lands with natural landscapes.

The following tasks have been accomplished in order to achieve the aim: one has determined natural and semi-natural plots that are potentially included in the local ecological network, taking into account the landscape and ecological and biological characteristics of these plots on a specific territory; one has developed the spatial structure of perspective elements of the ecological network and made an assessment of their spatial connectivity; one has discussed the relevance of research results for the practice of local ecological networks formation in Ukraine.

\section{Methodology of research and materials}

The study is based on the Convention on Biological Diversity (1992). Its goal is the development of strategies, plans and programs for the conservation and sustainable use of biological diversity in the territories. The methodological basis of the study is functional spatial analysis and synthesis. Spatial analysis involves the decomposition of a complex object (ecosystem) into its more simple elementary parts (biocenoses, biotopes) with the allocation of their individual properties and connections. The synthesis includes connection of components of the complex object (ecosystem) based on certain principles (integrity, systematicity, complexity, balance) and thereby constructs a new system (ecological network).

A lot of methods have been used to achieve the set goals. They are: comparative and geographic method for the establishment of the similarity and distinction of ecosystems by landscape features and 
the combination of the researched objects into one group on the basis of the systematization of data according to their functional purpose; the statistical method for the collection, systematization, analysis of information on the state of territories that have a special natural, ecological, aesthetic, historical and cultural, recreational value; the cartographic method for the visualization of settlement places of valuable flora and fauna, territories with degraded soils, modelling of structural elements of the ecological network; the geo-information method for analyzing and displaying geographic information about an object.

One has used landscape and ecological, agro-ecological and ecosystem approaches in spatial (territorial) planning of the structural elements of the ecological network.

MapInfo and Digitals software tools have been applied for cartographic works. One has also used photos that are available due to the free Google Earth service on the Internet and data from the Public Cadastral Map of Ukraine.

One has used indicators that characterize the degree of connectivity of its structural elements, calculated by the formulas, in order to assess the effectiveness of the major function of the ecological network, that is, the provision of biotic diversity and genetic heritage due to the migration of species (Hrodzynskyi D., 1993):

$$
\begin{gathered}
\alpha=(K-B+1) /(2 B-5), \\
\beta=K / B, \\
\gamma=L / 3(B-2),
\end{gathered}
$$

where $\mathrm{K}$ - number of connecting territories (green corridors), B - number of key territories (biocentres).

The higher the values of the $\alpha$-index, the more alternative ways migration of individuals from the key territory are provided (with $\alpha$ with limit from 0 to 1 ). The $\beta$-index characterizes the degree of development and complexity of the network of connecting territories (with $\beta$ with limit from 0 to 3 ): the network does not have any cycle at $\beta<1$, it has only one cycle at $\beta=1$ and several ones at $\beta>1$, all key territories are merged by the connecting territories in cycles that are optimum at $\beta=3$. The $\gamma$ index defines the degree of alternative choice of migration paths from one key territory to the other ones (with $\gamma \in$ with limit from 0 to 1), and the higher its value, the more extensive the network of connecting territories and the shorter migration paths between two arbitrarily selected key territories: none of the key territories is unrelated with each other at $\gamma=0$, each key territory is connected by the connecting territory, which is optimal at $\gamma=1$.

One has conducted the research on the example of the Stryi district of Lviv region, the territory of which belongs to the physical and geographical area of the Eastern Carpathian Foothills, and, according to geo-botanical zoning, to the Central European province of Stryi and Drohobych subprovince of oak forests and river and valley vegetation and meadows.

\section{Discussions and results}

The foundation of the ecological network formation is the natural ecosystem in the form of forest, shrub, meadow, swamp and other lands. In Stryi district, forest and shrub land vegetation account for $27.5 \%$ of the total area, swamps $-0.2 \%$, rivers and streams $-1.2 \%$, ponds and lakes $-0.6 \%$. Natural meadows were preserved mostly in the territories of the nature reserve fund, which is $4.2 \%$ (Table 1 ). Semi-natural lands are represented by hayfields $7.0 \%$ and pastures $9.8 \%$. The species composition of flora and fauna within the region is quite diverse. In particular, there are 9 species of flora and 5 species of fauna that are listed in the Red Data Book of Ukraine (State Enterprise..., 2019).

Unfortunately, there is no complete information on the distribution and number of species of flora and fauna on a specific territory in Ukraine. In addition, the Public Cadastral Map does not display the boundaries of the objects of the Nature Reserve Fund of local importance, since the relevant documentation on land management has not been developed. 
Table 1

Characteristics of Nature Reserve Fund of Stryi district of Lviv region

\begin{tabular}{|c|c|c|c|}
\hline Object & Title & Function & $\begin{array}{c}\text { Area, } \\
\text { ha }\end{array}$ \\
\hline \multicolumn{4}{|c|}{ National importance } \\
\hline $\begin{array}{l}\text { Monument of } \\
\text { landscape art }\end{array}$ & Pidhirtsi Park & $\begin{array}{c}\text { Preservation of plantations of plane trees and } \\
\text { hornbeam of natural origin }\end{array}$ & 8.3 \\
\hline \multicolumn{4}{|c|}{ Local importance } \\
\hline $\begin{array}{l}\text { Park-monument } \\
\text { of landscape art }\end{array}$ & $\begin{array}{l}\text { Park of the XIX } \\
\text { century }\end{array}$ & $\begin{array}{l}\text { Preservation of the park of the XIX century with } \\
\text { oak and beech plantations }\end{array}$ & 3.0 \\
\hline \multirow{4}{*}{$\begin{array}{l}\text { Natural } \\
\text { landmark }\end{array}$} & Birch wood & $\begin{array}{c}\text { Preservation of forest massif with birch plantations } \\
\text { of natural origin }\end{array}$ & 33.2 \\
\hline & Yosypovychi & $\begin{array}{l}\text { Preservation of forest massif with common oak } \\
\text { plantations of natural origin }\end{array}$ & 40.0 \\
\hline & Rozhirche & $\begin{array}{c}\text { Preservation of forest massif with prototype pure } \\
\text { beech plantations }\end{array}$ & 205.7 \\
\hline & Semyhyniv & $\begin{array}{c}\text { Preservation of rare vegetation types - } \\
\text { Swamp cranberries, the round-leaved sundew }\end{array}$ & 12.7 \\
\hline $\begin{array}{l}\text { Landscape } \\
\text { reserved area }\end{array}$ & $\begin{array}{l}\text { Morshyn } \\
\text { reserved area }\end{array}$ & $\begin{array}{l}\text { Preservation of plantations of beech, oak, } \\
\text { hornbeam, silver fir of natural origin. Breeding a } \\
\text { red deer population }\end{array}$ & 3084.6 \\
\hline $\begin{array}{c}\text { Complex } \\
\text { natural } \\
\text { monument }\end{array}$ & $\begin{array}{l}\text { Outcropping of } \\
\text { Vyhorodskyi } \\
\text { sandstone } \\
\end{array}$ & Preservation of a group of rocks made of sandstone & 1.0 \\
\hline $\begin{array}{c}\text { Botanical } \\
\text { natural } \\
\text { monument }\end{array}$ & $\begin{array}{c}\text { Franz Joseph's } \\
\text { oak }\end{array}$ & $\begin{array}{c}\text { Preservation of age-old oak. Age of the tree is } \\
\text { about } 250 \text { years old }\end{array}$ & 0.05 \\
\hline $\begin{array}{l}\text { Hydrological } \\
\text { natural } \\
\text { monument }\end{array}$ & Well № 6 & Preservation of mineral water source & 0.3 \\
\hline
\end{tabular}

It is done by the authors on the basis of data (State Enterprise..., 2019; Nature and Reserve Fund..., 2019).

One has allocated crucial territories (ecological nuclei) within the limits of forest massifs, where reserved objects are located, in designing the ecological network of Stryi district. One has also taken into account centers of the existence of species of flora and fauna of the Red Data Book of Ukraine, lands of recreation.

Therefore, in this work, we mapped the approximate location of valuable flora and fauna and objects of Nature Reserve fund within the region (Fig. 1).

The main criteria for selecting plots for connecting territories (green corridors) are: maximum consideration of natural boundaries; sufficiency of latitude and longitude to ensure the migration of species, their reproduction and the experience of their unfavorable conditions; the edaphic factors of the green corridor should be similar or close to the edaphic factors of the ecological nuclei which it unites; there should not be migration barriers or other factors within the corridor that can prevent migration and species placement; they must contain well-preserved vegetation and have a great biological diversity; they may contain areas where there are rare, relic or endemic species of flora and fauna or rare plant groups that are not present in ecological nuclei for some reason (Deodatus F., Protsenko L. and others, 2010). It is rather complicated to adhere to the above-mentioned criteria in designing connecting territories in Ukrainian realities taking into account the fact that economic activity has led to the insularization of natural ecosystems (forests, natural reservoirs, swamps). 


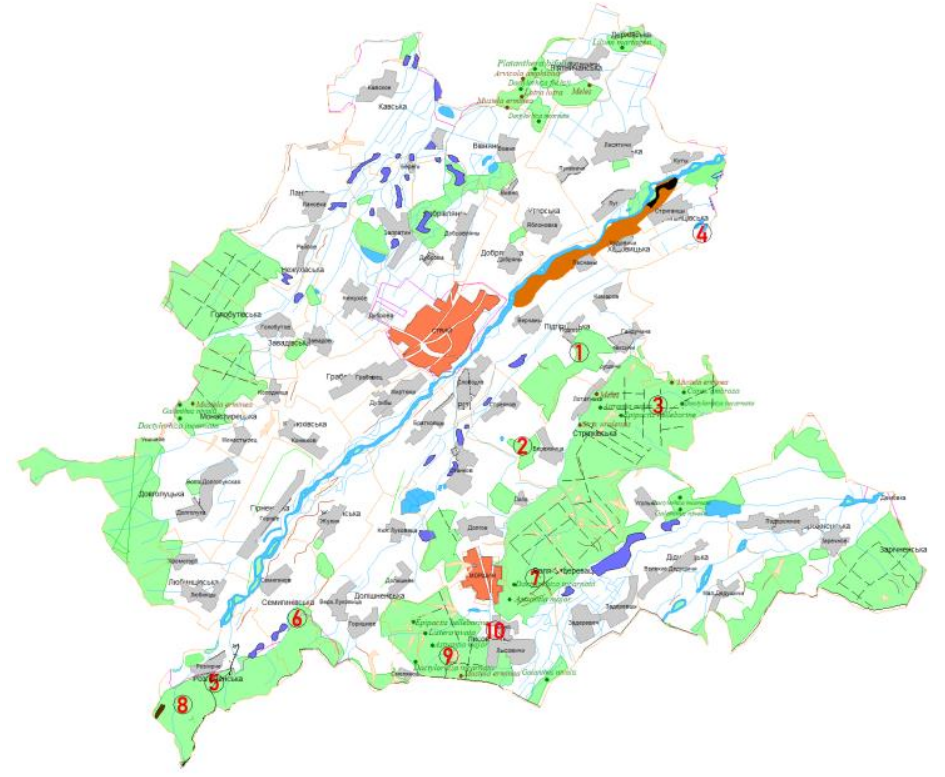

Fig. 1. Location of reserved objects and valuable species of flora and fauna within Stryi district: 1 - Monument of landscape art "Pidhirtsi park"; 2 - Park-monument of landscape art "Park of the $19^{\text {th }}$ century"; 3 - Natural landmark "Birch wood"; 4 - Natural landmark "Yosypovychi"; 5 - Natural landmark "Rozhirche"; 6

- Natural landmark "Semyhyniv"; 7 - Landscape reserved area "Morshyn reserved area"; 8 - Complex natural monument "Baring of Vyhorodskyi sandstone"; 9 - Botanical natural monument "Franz Joseph's Oak"; 10 Hydrological natural monument "Well №6" (developed by authors)

Most of the projected migration routes consist of semi-natural lands (hayfields and pastures), and in some places from unnatural lands (mainly arable lands).

The criteria for establishing buffer zones are determined by the peculiarity of the crucial and connecting territories, and buffer territory is formed for their protection. The buffer zones in the ecological network are designed around crucial territories in those places where the risk of negative impact of anthropogenic activity on adjacent spaces (settlements, lack of natural lands, etc.) predominates. Arable lands are partially included in the buffer zones. One should conduct safe farming (organic) on these lands.

Renewable territories include territories the natural state of which has been disturbed due to human activity and territories with active expressions of negative geodynamic processes for which it is necessary and possible to recreate the natural vegetation and repatriate the species of flora and fauna (the transfer of artificially propagated plants to natural conditions). The area of the renewable territory can be attached to or become part of the crucial ecological networks, after taking appropriate measures for re-naturalization. One has recommended creating renewable territories within the region on agricultural land plots, including arable lands with medium-eroded soils (320 hectares) and waterlogged flood plain soils (1166 hectares).

The design ecological network of the district includes 5 crucial territories with a total area of 9335.97 hectares; 9 connecting territories with the total area of 2945.0 hectares; renewable territories with a total area of 4626.87 hectares; buffer zones with a total area of 1503.44 hectares. The total area of the structural elements of the ecological network is 18411.27 hectares (Fig. 2).

An estimation of the degree of connectivity of crucial territories of the design ecological network indicates the following: $\alpha=1$ - indicates the sufficient number of alternative ways of migration of individuals from some crucial territories to others, that is, the ecological network ensures the fulfilment of the bio-migration function; $\beta=2$ - points to several cycles, that is, most of the crucial territories are interconnected by connecting territories into a single whole; $\gamma=1$ - indicates that each crucial area is bound by the connecting territory. 


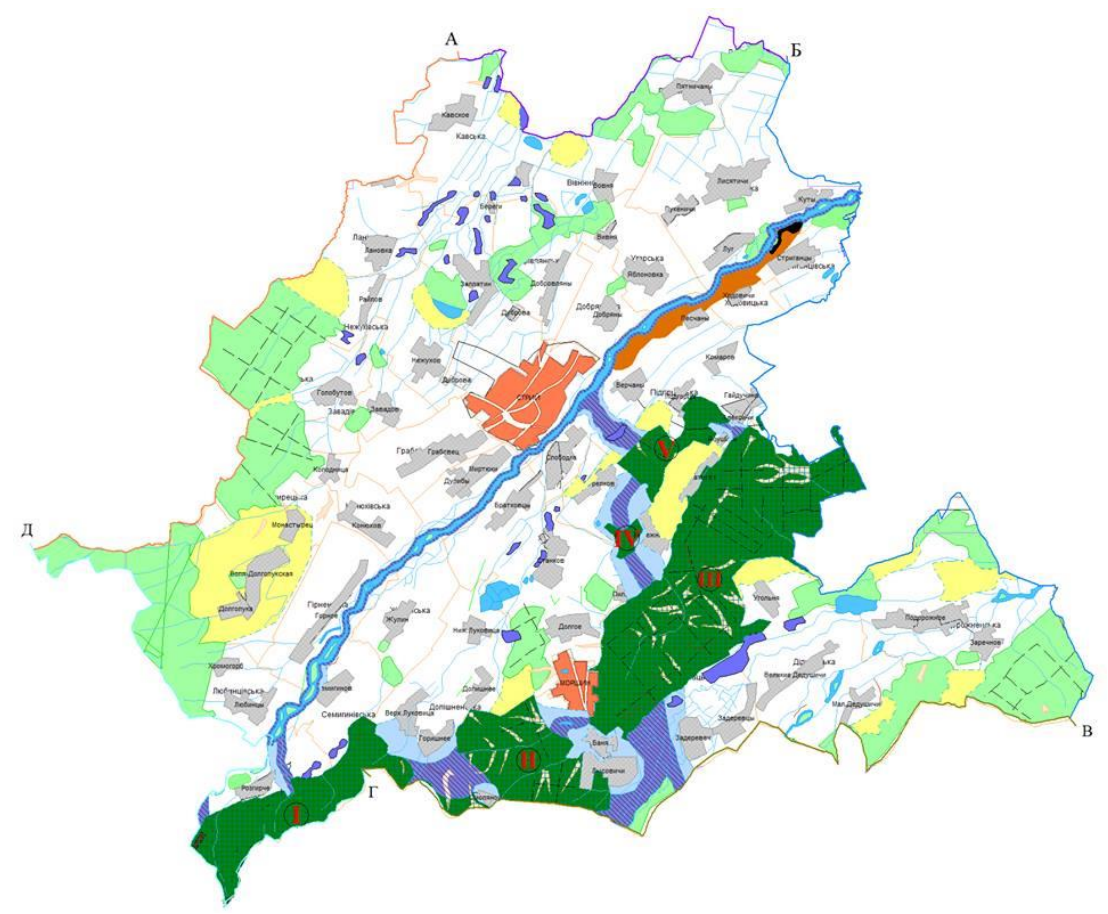

Fig. 2. The scheme of promising structural elements of the ecological network of Stryi district: - crucial territories $\square$ - connecting territories; $\square$ - renewable territories (developed by the authors)

In general, the structural and functional system of the design ecological network includes: 1) reserved territories, which have a special regime of protection and use for the purpose of their conservation; 2) territories that were in economic (agricultural, forestry, and water industry) use but they should be transferred to the category of nature protection territories; 3) territories which will be in further economic use with some restrictions.

Therefore, one should consider the ecological network in two conceptual directions - strict nature protection and nature protection with controlled use of natural resources (Bennett G., 2004). That is, the concept of ecological networks is interconnected with the concept of ecosystem services. One explains ecosystem services as the potential of natural processes and components for the provision of goods and services used directly or indirectly to meet human needs. Moreover, these services perform regulatory functions, habitat functions, production functions, information functions. Habitat function lies in the fact that natural ecosystems provide living space for flora and fauna species. In turn, these species are of vital importance for the maintenance of most ecosystem functions, so support of habitat is an extremely principal prerequisite for the direct or indirect acquisition of goods and services for ecosystems (De Groot R. S., Wilson M. A., Boumans R. M. J., 2002). In this context, the biological and landscape diversity of the territories is a natural capital that provides people with air, water, soil, recreation areas, etc. In our opinion, this position should be placed in the strategy of social and economic development and planning of territories at the state, regional and local levels.

We believe that the formation of ecological networks of local importance is the basis for the establishment and maintenance of proper functioning of biosphere reserves, which perform three interrelated functions: the function of conservation of genetic resources, species, ecosystems and landscapes, the function of sustainable social and economic development, and inventory and logistics function to support demonstration projects, environmental education and training, as well as research and monitoring in the context of implementing local, national and global problems of preserving environment and sustainable development (Zahorodnii A., Cherinko P., Poltoratska T., 2014). The development of biosphere reserves is a regional task, but activities in this direction take place in obligatory and close cooperation with local governments and the local population. Despite the fact that Ukraine has a legal basis for the formation of ecological networks, the process is complex, lasting and has a number of problems. At the local level, it requires solving a set of tasks, among which we have identified the most relevant ones: an arrangement of the scheme of the ecological network with all 
landowners and land users; development and establishment of land use regimes for structural elements of the ecological network; development and implementation of measures for land re-naturalization. The fulfillment of these tasks requires the improvement of institutional and managerial mechanisms in the sphere of nature protection land use. First of all, it is necessary to develop an effective mechanism for encouraging landowners and land users to use resources; to increase investment in regulation and management of environmental activities; to ensure the appropriate level of environmental education and environmental public awareness campaign; to provide consulting services to local selfgovernment bodies when developing ecological network development programs at the local level.

\section{Conclusions and proposals}

1. Ukraine supports the idea of conservation and renovation of biological diversity of territories due to the implementation of the concept of ecological networks, considering the existing legislation and drafts of design ecological network schemes at the regional level. However, the principle of the integrity of ecosystem functions, as well as the location of the objects of Nature Reserve Fund and valuable species of flora and fauna are not fully taken into account when designing structural elements of ecological networks of the regional level. In our opinion, one should resolve these issues at the local level, which will allow more detailed and objective analysis of the natural potential of the territories and the actual state of land use.

2. One has carried out the study on the development of an ecological network at the local level on the example of Stryi district of Lviv region, within which there are 10 objects of the Nature Reserve Fund, as well as 9 species of flora and 5 species of fauna which are listed in the Red Data Book of Ukraine. Natural vegetation is mainly preserved in forests, which perform mainly ecological functions, but forest lands are located fragmentarily. Expediency of developing an ecological network is obvious. It will allow forming a whole framework of protected areas in order to preserve the places of settlement and growth of valuable species of animal and plant life, ways of migration of animals due to a combination of objects of the Nature Reserve Fund.

3. An estimation of the degree of connectivity of the design crucial territories indicates the high efficiency of the migration function of the ecological network of the district. However, most of the migration routes (green corridors) are formed from semi-natural and unnatural lands (hayfields, pastures, arable lands), which complicates the practical side of the implementation of this project. It is necessary to improve administrative and institutional mechanisms in the sphere of nature protection land use, in particular: to develop tools for encouraging landowners and land users to carry out environmental activities; to increase investments in re-naturalization of lands; to carry out environmental public awareness campaign among the population; to provide consulting services on environmental protection.

\section{References}

1. Bennett G., Wit P. (2001) The Development and Application of Ecological Networks: a Review of Proposals, Plans and Programmes. Amsterdam: AIDEnvironment. $136 \mathrm{p}$.

2. Bennett G., Mulongoy K. J. (2006) Review of Experience with Ecological Networks, Corridors and Buffer Zones. Secretariat of the Convention on Biological Diversity, Montreal, Technical Series No. 23. 100 p.

3. Jongman R.H.G, Külvik M., Kristiansen I. (2004) European Ecological Networks and Greenways. Landscape and Urban Planning, No 68, pp. 305-319.

4. Opdam P., Steingröver E., Van Rooij S. (2006) Ecological networks: A spatial concept for multi-actor planning of sustainable landscapes. Landscape and Urban Planning, No 75, pp. 322-332.

5. Boitani L., Falcucci A. Maiorano L, Rondinini C. (2007) Ecological networks as conceptual framework or operational tools in conservation. Conservation Biology, No 21 (6), pp. 1414-1422.

6. Statistical Yearbook of Ukraine for the year 2017. Edited by Verner I. 540 p. (In Ukrainian)

7. On Ecological network (Law of Ukraine). June 24, 2004. № 1864-IV. URL: https://zakon.rada.gov.ua/laws/show/1864-15/conv (Accessed 2 March, 2019) (In Ukrainian)

8. Kahalo O. (2009) Building an Ecological network in Ukraine: Principles, Problems, Perspectives. L.: Institute of the Carpathian Ecology of the National Academy of Sciences of Ukraine. pp. 10-13. (In Ukrainian)

9. Kostiushyn V., Vasyliuk O., Kolomytsev H. An Indicative Scheme of the Ecological network of the Pivdennyi Bug River Basin and Methodical Approaches to the Creation of the National Ecological network of Ukraine. Kyiv: Institute of Zoology named after. I. Shmalhauzen of National Academy of Sciences, National Ecological Center of Ukraine, 2011. 28 p. (In Ukrainian) 
10. Hrodzynskyi D. (1993) Foundations of Landscape Ecology: Manual. K.: Lybid. 224 p. (In Ukrainian)

11. State Enterprise "Stryi Forestry Enterprise». Official site. URL: http://stryi-lisgosp.com.ua/) (Accessed 6 February, 2019)

12. Nature and Reserve Fund of Ukraine: Official site. URL: http://pzf.menr.gov.ua/ (Accessed 12 February, 2019)

13. Deodatus F., Protsenko L. and others (2010) The Creation of Green Corridors in Ukraine. K.: "Printing House "BusinessPolygraph". 160 p. (In Ukrainian)

14. Bennett G. (2004) Integrating Biodiversity Conservation and Sustainable Use: Lessons Learned From Ecological Networks. IUCN, Gland, Switzerland, and Cambridge, UK. 55 p.

15. De Groot R. S., Wilson M. A., Boumans R. M. J. (2002) A Typology for the Classification, Description and Valuation of Ecosystem Functions, Goods and Services. Ecological Economics, No 41, pp. 393-408.

16. Zahorodnii A., Cherinko P., Poltoratska T. (2014) National Network of Biosphere Reserves of UNESCO in Ukraine (to the 40th anniversary of the National Committee of Ukraine on the UNESCO program "Human and Biosphere). Bulletin of the National Academy of Sciences of Ukraine, № 2, pp. 55-66. (In Ukrainian)

Information about authors:

Nataliia Stoiko, Ph.D, Associate Professor of Department of Land Organization of Lviv National Agrarian University. Address: Lviv-Dublyany, Ukraine, 80381, phone: +38 06713276 16, e-mail: $\underline{\text { n_stoiko@ukr.net }}$ Fields of interest: land management, land use planning, environment protection.

Oksana Cherechon, Ph.D, Associate Professor of Department of Land Organization of Lviv National Agrarian University. Address: Lviv-Dublyany, Ukraine, 80381, phone: +38 09753009 33, e-mail: okcherechon@gmail.com

Fields of interest: environmental economics, organization of the territory, land protection. 